\title{
Sustainable Fertilizer Level for Winter Wheat in Different Rainfall Regions on the Loess Plateau of China
}

\author{
Xuechun Wang ${ }^{1}$, Shishun Tao ${ }^{1}$, Mingde $\mathrm{Hao}^{2}$, and Wei $\mathrm{Li}^{3}$ \\ ${ }^{1}$ School of Life Science and Technology, \\ Southwest University of Science and Technology, \\ Mianyang, Sichuan 712100, China \\ ${ }^{2}$ Institute of Soil and Water Conservation, CAS \& MWR, \\ Yangling, Shaanxi 712100, China \\ ${ }^{3}$ Fujian Academy of Agricultural Sciences Central Laboratory Fuzhou, \\ Fujian 350003, China
}

\begin{abstract}
Higher fertilization on winter wheat increased the fluctuation of winter wheat yield in different rainfall years and impacted the sustainable development of winter wheat production on the Loess Plateau. Based on the long term field experimental data at Chagnwu Agricultural Station, this paper evaluated the EPIC model. And this paper also suggested a sustainable fertilizer level for winter wheat, based on the analysis of simulation results in different rainfall regions. Results of this study indicated that: 1) The EPIC model simulated both winter wheat yields and soil water among different fertilizer levels well, with the mean $\mathrm{R}$ value of 0.91 and 0.89 respectively. 2) With the increasing of fertilizer, the value of IRFG (Increase Rate of Grain yield by Fertilizer) and WUEG (Water Using Rfficiency for Grain yield) became higher, when soil water in deep soil was not be used excessively; however, the value of IRFG became lower, when soil water in deep soil was used excessively. 3) In the semi-humid region, fertilizer for winter wheat should be from $\mathrm{N}_{4}$ to $\mathrm{N}_{5}$; in the semi-humid and drought-prone region and in the semi-arid region, it should be from $\mathrm{N}_{3}$ to $\mathrm{N}_{4}$; in the semi-arid and drought-prone region, it should be lower than $\mathrm{N}_{3}$.
\end{abstract}

Keywords: The loess plateau, Winter wheat, Fertilizer, EPIC model.

\section{O Introduction}

Winter wheat is a major food and feed grain crop in the world. It occupies a large area $(82 \%)$ of the Loess Plateau rain-fed region of china [1]. Wheat is mostly grown under dry land conditions, therefore, its growth, development and yield depended mainly on available water and fertilizer. An increase in fertilization can stimulate deeper rooting of winter wheat, making a greater quantity of stored soil-water available to the plant, thereby reducing potential water stress and harvesting more yields [2, 3]. With the spreading and applying of fertilizer, winter wheat yield on the Loess Plateau had increased from an average of $1696 \mathrm{~kg} / \mathrm{hm}^{2}$ for the period of $1980-1985$ to $3438 \mathrm{~kg} / \mathrm{hm}^{2}$ for 1986-2010. However, larger above ground biomass and transpirational leaf area, 
stimulated by increased fertilizer, results in greater transpiration demands and amount of water loss from the crop canopy [4]. Therefore, this increased productivity had increase soil water depletion and reduced available soil water in deep soil [5]. Excessive consumption of soil water has become the key reason for soil desiccation and yield fluctuation in high-yield land farm [6]. It is urgently need to determine a sustainable fertilizer level for this region as well as the similar region in the world.

To carry out an experiment in different regions and in a long period may found out an answer for the sustainable fertilizer level in different rainfall regions. However, it is a long-term endeavor that is both expensive and time-consuming. An alternative approach is to use computer model to simulate soil water content and crop yield under different fertilizer levels in different rainfall regions based on local situations (soil, crop and climate etcetera). Several models have been developed to simulate soil water and crop yield [7-9]. One such model is the EPIC model that simulates the soil water and crop yield simultaneously with the help of its two sub-models (growth model and hydrology model) [10]. Wang and Li [11] evaluated EPIC model for crop yield and soil water content among different cropping systems (spring maize, winter wheat and alfalfa) on the Loess Plateau. They found that EPIC model estimate soil water and crop yield well with the new database built up for the Loess Plateau.

The primary objective of this study was to determine a sustainable fertilizer level for winter wheat in different rainfall regions on the Loess Plateau. The secondary objective was to evaluate EPIC model for crop yield and soil water among different fertilizer levels, using a long-term experimental data at Changwu Agricultural Station.

\section{$1 \quad$ Materials and Methods}

\subsection{Field Experiment}

The field experiment was carried out at Changwu Agricultural Station from 1985 to 2000. It consisted of three fertilization treatments (table 1) with three replications in 9 plots of $10.26 \times 6.5 \mathrm{~m}$ (with a buffer zone of $1 \mathrm{~m}$ between plots). Plots were arranged as a randomized complete block design. All fertilizers were mixed and applied at sowing, and winter wheat was sown at the rate of $19.5 \mathrm{~kg} / \mathrm{hm}^{2}$, using a no-till disk drill with the row space of $0.25 \mathrm{~m}$. For grain yield determination, the plots were harvested manually. Soil samples were taken by core break method [12] in $0.1 \mathrm{~m}$ layers to the depth of $3 \mathrm{~m}$ soil. Soil water content was measured (gravimetrically) for each soil sample by the oven-drying method [13].

Table 1. Fertilizer treatments for the winter wheat at Changwu Agricultural Station from 1985 to 2000

\begin{tabular}{ccc}
\hline Treatments & $\mathrm{N}\left(\mathrm{kg} / \mathrm{hm}^{2}\right)$ & $\mathrm{P}_{2} \mathrm{O}_{5}\left(\mathrm{~kg} / \mathrm{hm}^{2}\right)$ \\
\hline $\mathrm{CK}$ & 0 & 0 \\
$\mathrm{~N}$ & 120 & \\
$\mathrm{NP}$ & 120 & 60 \\
\hline
\end{tabular}




\subsection{EPIC Model}

EPIC is a widely tested and adopted process-based agro-ecological model originally built to quantify the effects of soil erosion on productivity $[10,14]$. Currently the model has evolved into a comprehensive model capable of simulating photosynthesis, evapo-transpiration and other major plant and soil processes [15]. The model runs on a daily time step and needs daily weather data as well as information on soil properties, specific crop growth parameters and farm management practices [16].

Based on crop parameters and other related parameters, the EPIC model can calculate the uptakes of soil water and nutrients by crop, estimate the impacts of temperature, water, nutrients (N, P and $\mathrm{k}$ ), air and salt stresses on crop biomass accumulation and crop yield by daily step [17]. For soil water, the EPIC model contains algorithms that allow for a description of the hydrological balance at the small watershed [18]. Calculated hydrological processes include snowmelt, surface runoff, infiltration, soil water content, percolation, lateral flow, water table change, and evapo-transpiration at a daily time step, details was given out by Sharply and Williams [19] and Williams et al. [15].

\subsection{Methods}

\subsubsection{Evaluation of the EPIC Model}

In this study, six statistical values were used to evaluate the model performance as followings. Root Mean Square Error (RMSE), Relative Root Mean Square Error (RRMSE), Relative Error (RE), Model Efficiency (ME), Correlation Coefficient (R), Determination Coefficient $\left(\mathrm{R}^{2}\right)$, detailed information for these equations can found in Wang and $\mathrm{Li}$ [11] and Ko et al. [20].

\subsubsection{Calculation for WUEG and FUEG}

Water-use efficiency was calculated as equation 1 [21]:

$$
\mathrm{WUEG}=\frac{\mathrm{GY}}{\mathrm{ET}}
$$

Where WUEG was water-use efficiency for the grain yield, GY was the grain yield and ET was the cumulative evapo-transpiration over the growing season which was calculated using the water balance equation (equation 2):

$$
\mathrm{ET}=(P+I+\mathrm{C})-(R+D)-\mathrm{D} S
$$

Where $\mathrm{P}$ was precipitation, I was irrigation, $\mathrm{C}$ was upward flow into the root zone, $\mathrm{R}$ was surface runoff, and $\mathrm{D}$ was downward drainage out of the root zone. DS was the change of available soil water in winter wheat field, which was calculated by equation 3.

$$
\mathrm{DS}=\mathrm{ASP}-\mathrm{ASH}
$$


Where ASP was available soil water in 0-7 m soil when winter wheat was sown, ASH was available soil water in 0-7 $\mathrm{m}$ soil when winter wheat was harvested.

Since the experimental field was terraced, and located in the Loess Plateau, surface runoff was ignored. The groundwater table was very low, so the upward flow into the root zone and the downward drainage out of the root zone were negligible. Consequently, the soil water balance equation was reduced to equation 4 .

$$
\mathrm{ET}=\mathrm{P}-(\mathrm{ASP}-\mathrm{ASH})
$$

Increase rate of grain yield for different fertilizer level was calculated by equation 5, 6 and 7.

$$
\begin{gathered}
\text { IRFG }=\frac{\mathrm{DG}}{\mathrm{DN}} \\
\mathrm{DG}=\mathrm{GN}_{\mathrm{m}}-\mathrm{GN}_{\mathrm{m}-1}, 6 \geq \mathrm{m} \geq 1 \\
\mathrm{DN}=\mathrm{N}_{\mathrm{m}}-\mathrm{N}_{\mathrm{m}-1}, 6 \geq \mathrm{m} \geq 1
\end{gathered}
$$

Where DG was increased yield from fertilizer level $\mathrm{N}_{\mathrm{m}-1}$ to fertilizer $\mathrm{N}_{\mathrm{m}}$, DN was increased fertilizer of $\mathrm{N}$ from fertilizer level $\mathrm{N}_{\mathrm{m}-1}$ to fertilizer $\mathrm{N}_{\mathrm{m}} ; \mathrm{GN}_{\mathrm{m}}$ was grain yield of winter wheat under fertilizer level of $\mathrm{N}_{\mathrm{m}}, \mathrm{GN}_{\mathrm{m}-1}$ was grain yield of winter wheat under fertilizer level of $\mathrm{N}_{\mathrm{m}-1} ; \mathrm{N}_{\mathrm{m}}$ was amount of $\mathrm{N}$ in fertilizer level of $\mathrm{N}_{\mathrm{m}}, \mathrm{N}_{\mathrm{m}-1}$ was amount of $\mathrm{N}$ in fertilizer level of $\mathrm{N}_{\mathrm{m}-1}$.

\subsubsection{Description of the Development of Dry Soil Layer}

In order to compare the development of dry soil layer among different fertilizer levels and different regions, parameters as following were considered in this study. 1) SMDDT Period, a Period in which soil water decreased and dry soil layers thickened continuously; 2) SSMD Year, a year in which steady dry soil layer built; 3) Max DSL, Maximum depth of dry soil layer occurred; 4) SSL Range, a depth range in which soil water content was stable after steady dry soil layer built; 5) SMC Range, a depth range in which soil water content was unstable after steady dry soil layer built; 6) SWU Depth, Maximum depth in which soil water was used; 7) DSLD Range, a depth range in which dry Soil Layers occurred; 8) SD Speed, dry soil layer building speed.

Parameters of SMDDT Period and SSMD Year described the time needed to building dry soil layer; Max DSL and DSLD Range presented the distribution depth of dry soil layer; SSL Range and SMC Range told us the stability of dry soil layer; SD speed indicated the building speed of dry soil layer.

\subsubsection{Statistical Method}

Analysis of variance (ANOVA) was used to test the difference in grain yield, wateruse efficiency and fertilizer-use efficiency among different treatments and different regions. Mean comparisons were made by the LSD (the least significant difference) method with $\mathrm{P}<0.05$ and $\mathrm{P}<0.01$ respectively. The analyses were conducted using the SPSS program [22]. 


\subsection{Design for the Simulation}

Mean annual rainfall at Luochuan and Changwu were $622 \mathrm{~mm}$ and $584 \mathrm{~mm}$ respectively; at Yan'an and Shouyang were $535 \mathrm{~mm}$ and $455 \mathrm{~mm}$ respectively. In this study, Luochuan and Yan'an were selected as the representation of semi-humid region and semi-arid region respectively; Changwu as the representation of semihumid and drought-prone region; Shouyang as the semi-arid and drought-prone region on the Loess Plateau. Fertilizer treatments for each regions consisted of 7 fertilizer treatments as table 2 .

Table 2. Fertilizer treatments for winter wheat in different rainfall regions on the Loess Plateau of China

\begin{tabular}{ccccccccc}
\hline Fertilizer & \multicolumn{3}{c}{ Luochuan $\left(\mathrm{kg} / \mathrm{hm}^{2}\right)$} & \multicolumn{2}{c}{ Changwu $\left(\mathrm{kg} / \mathrm{hm}^{2}\right)$} & \multicolumn{2}{c}{ Yan'an $\left(\mathrm{kg} / \mathrm{hm}^{2}\right)$} & \multicolumn{3}{c}{ Shouyang $\left(\mathrm{kg} / \mathrm{hm}^{2}\right)$} \\
level & $\mathrm{N}$ & $\mathrm{P}$ & $\mathrm{N}$ & $\mathrm{P}$ & $\mathrm{N}$ & $\mathrm{P}$ & $\mathrm{N}$ & $\mathrm{P}$ \\
\hline $\mathrm{N}_{0}$ & 0 & 0 & 0 & 0 & 0 & 0 & 0 & 0 \\
$\mathrm{~N}_{1}$ & 90 & 45 & 90 & 45 & 90 & 45 & 90 & 45 \\
$\mathrm{~N}_{2}$ & 120 & 60 & 120 & 60 & 120 & 60 & 120 & 60 \\
$\mathrm{~N}_{3}$ & 150 & 75 & 150 & 75 & 150 & 75 & 150 & 75 \\
$\mathrm{~N}_{4}$ & 180 & 90 & 180 & 90 & 180 & 90 & 180 & 90 \\
$\mathrm{~N}_{5}$ & 210 & 105 & 210 & 105 & 210 & 105 & 210 & 105 \\
$\mathrm{~N}_{6}$ & 240 & 120 & 240 & 120 & 240 & 120 & 240 & 120 \\
\hline
\end{tabular}

First, we input soil data, crop data, meteorological data and management data into the EPIC model for each selected region. Second we evaluate the EPIC model using the long-term experimental data at Changwu Agricultural Station. Third we run the EPIC model from 1961 to 2000, and out put the simulated winter wheat yield year by year and soil water day by day. At last we analyzed the fluctuation of crop yield and soil water during a long period, based on the simulation results. Considering the sustainable using of soil water and production of winter wheat, we pointed out a sustainable fertilizer level for different rainfall regions on the Loess Plateau.

\section{Results}

\subsection{Evaluation Results of the EPIC Model}

\subsubsection{Winter Wheat Yield}

Measured mean annual winter wheat yield were 1.40, 2.28 and $2.98 \mathrm{t} / \mathrm{hm}^{2}$; Simulated mean annual winter yield were 1.46, 2.30 and $2.77 \mathrm{t} / \mathrm{hm}^{2}$ for CK, N and NP respectively. Table 3 showed that simulated winter wheat yield were slightly higher for $\mathrm{CK}$ and $\mathrm{N}$ treatment and were slightly lower for NP treatment, comparing with measured yield. Paired-t test demonstrated the difference between simulated and 
measured winter wheat yield for each treatment was not significant with $\mathrm{P}=0.05$. EPIC model simulated mean annual winter wheat yield well, with the $\mathrm{R}$ vale of 0.91 , 0.93 and 0.89 for $\mathrm{CK}, \mathrm{N}$ and NP respectively.

Table 3. Comparison of simulated and measured winter wheat yield for different fertilizer levels at Changwu Agricultural Station

\begin{tabular}{ccccccc}
\hline & $\begin{array}{c}\text { Annual mean yield }\left(\mathrm{t} / \mathrm{hm}^{2}\right) \\
\text { Measured }\end{array}$ & Simulated & $\begin{array}{c}\text { RE } \\
(\%)\end{array}$ & $\mathrm{R}$ & $\begin{array}{c}\text { RMSE } \\
\left(\mathrm{t} / \mathrm{hm}^{2}\right)\end{array}$ & $\begin{array}{c}\text { RRMSE } \\
(\%)\end{array}$ \\
\hline $\mathrm{CK}$ & 1.40 & 1.46 & 4.4 & $0.91^{* *}$ & 0.41 & 29 \\
$\mathrm{~N}$ & 2.28 & 2.30 & 1.2 & $0.93^{* *}$ & 0.53 & 23 \\
$\mathrm{NP}$ & 2.98 & 2.77 & -7.1 & $0.89^{* *}$ & 0.86 & 28 \\
\hline
\end{tabular}

Little difference between ME and $\mathrm{R}^{2}$ value (figure 1) presented the variance of winter wheat yield in different years was simulated well by EPIC model with the RRMSE value of $29 \%, 23 \%$ and $28 \%$ respectively (table 3 ). Comparing with that for NP, winter wheat yield was simulated better with a higher value of $\mathrm{R}^{2}$ for $\mathrm{CK}$ and $\mathrm{N}$ (figure 1).
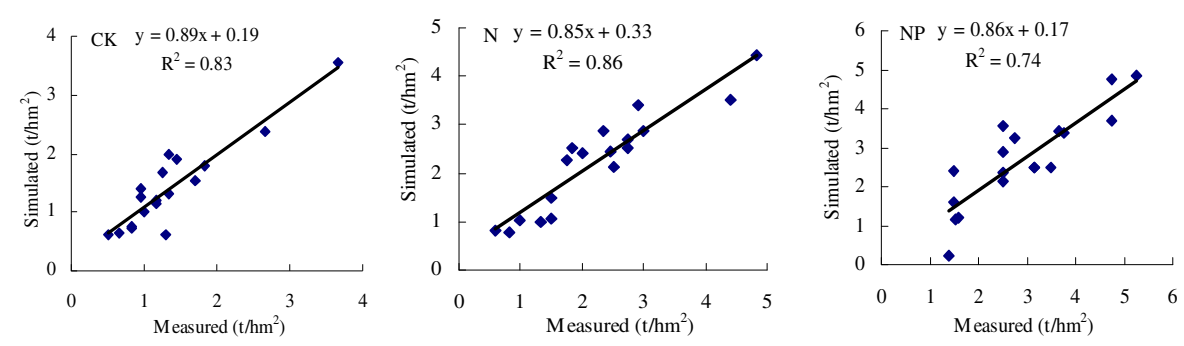

Fig. 1. Comparison of simulated and measured winter wheat yield for different fertilizer levels at Changwu Agricultural Station

\subsubsection{Soil Water}

Measured mean available soil water in 0-3 m soil were 120, 96 and $85 \mathrm{~mm}$ for CK, N and NP respectively; simulated mean value were 113, 97 and $92 \mathrm{~mm}$ respectively. The value of mean available soil water estimated by EPIC model was slightly higher than that of simulated for N and NP, and slightly lower for CK (table 4). Paired-t test indicated the difference between simulated and measured available soil water in 0-2 $\mathrm{m}$ soil for each treatment was not significant with the $\mathrm{P}$ value of 0.05 . EPIC model estimated mean annual available soil water well, with the $\mathrm{R}$ vale of $0.90,0.96$ and 0.81 for $\mathrm{CK}, \mathrm{N}$ and NP respectively. 
Table 4. Comparison of simulated and measured available soil water in 0-3m soil for different fertilizer levels at Changwu Agricultural Station

\begin{tabular}{ccccccc}
\hline & $\begin{array}{c}\text { Annual available soil water }(\mathrm{mm}) \\
\text { Measured }\end{array}$ & $\begin{array}{c}\text { RE } \\
(\%)\end{array}$ & R & $\begin{array}{c}\text { RMSE } \\
(\mathrm{mm})\end{array}$ & $\begin{array}{c}\text { RRMSE } \\
(\%)\end{array}$ \\
\hline $\mathrm{CK}$ & 120 & 113 & -5.8 & 0.90 & 22.38 & 19 \\
$\mathrm{~N}$ & 96 & 97 & 1.0 & 0.96 & 16.44 & 17 \\
$\mathrm{NP}$ & 85 & 92 & 8.2 & 0.81 & 18.37 & 23 \\
\hline
\end{tabular}

Little difference between $\mathrm{ME}$ and $\mathrm{R}^{2}$ value (figure 2) showed the variance of available soil water in different years for each fertilizer level was simulated well by EPIC model with the RRMSE value of $19 \%, 17 \%$ and $23 \%$ respectively (table 4 ). Comparing with that for NP, available soil water in 0-3 m soil was simulated better with a higher value of $\mathrm{R}^{2}$ for $\mathrm{CK}$ and $\mathrm{N}$ (figure 2).
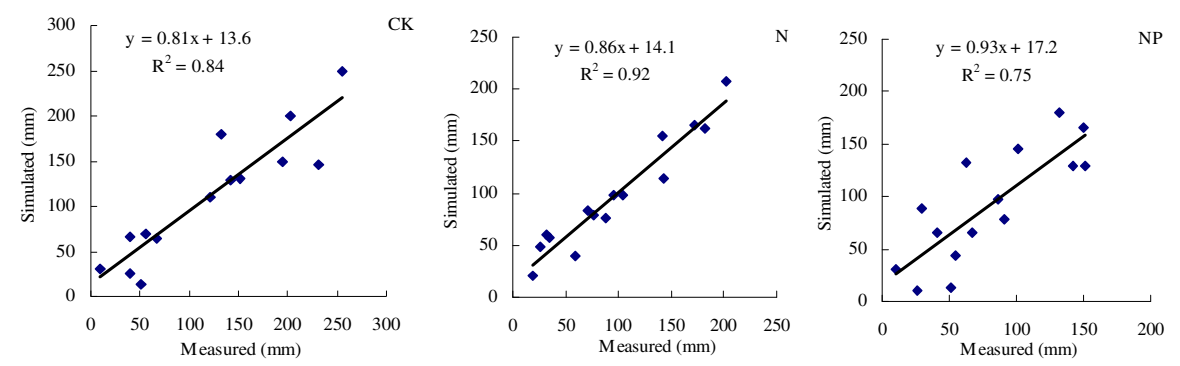

Fig. 2. Comparison of simulated and measured annual mean available soil water in $0-3 \mathrm{~m}$ soil for different fertilizer levels at Changwu Agricultural Station

\subsection{Simulation Results of Winter Wheat Yield and Soil Water}

\subsubsection{Winter Wheat Yield}

The difference of mean annual winter wheat yield was highly significant $(\mathrm{P}=0.01)$ in different rainfall regions (table 5). Mean value of annual winter wheat yield were 2.77, 2.70, 1.97 and $1.00 \mathrm{t} / \mathrm{hm}^{2}$, with standard deviation of $1.52,1.59,1.40$ and 0.84 $\mathrm{t} / \mathrm{hm}^{2}$. With the increase amount of precipitation, more winter wheat yield was founded at Luochuan and Changwu.

The difference of winter wheat yield among $\mathrm{N}_{0}, \mathrm{~N}_{1}, \mathrm{~N}_{2}$, and $\mathrm{N}_{3}$ fertilizer level was significant (table 5). The difference of winter wheat yield between $N_{5}$ and $N_{6}$ fertilizer level was not significant. Before N3 fertilizer level, winter wheat yield increased with the increase amount of fertilizer application; after N4 fertilizer level, the impact of fertilizer on winter wheat was different in different rainfall regions (table 5). 
Table 5. Difference of winter wheat yield among different fertilizer levels in different rainfall regions on the Loess Plateau of China

\begin{tabular}{ccccc}
\hline Fertilizer level & Luochuan & Changwu & Yan'an & Shouyang \\
\hline $\mathrm{N}_{0}$ & $1.20 \mathrm{a}$ & $1.44 \mathrm{a}$ & $0.96 \mathrm{a}$ & $0.53 \mathrm{a}$ \\
$\mathrm{N}_{1}$ & $1.83 \mathrm{~b}$ & $1.94 \mathrm{~b}$ & $1.36 \mathrm{~b}$ & $0.69 \mathrm{~b}$ \\
$\mathrm{~N}_{2}$ & $2.53 \mathrm{c}$ & $2.45 \mathrm{c}$ & $1.76 \mathrm{c}$ & $0.90 \mathrm{c}$ \\
$\mathrm{N}_{3}$ & $3.00 \mathrm{~d}$ & $2.87 \mathrm{~d}$ & $2.08 \mathrm{~d}$ & $1.07 \mathrm{~d}$ \\
$\mathrm{~N}_{4}$ & $3.44 \mathrm{e}$ & $3.24 \mathrm{e}$ & $2.43 \mathrm{e}$ & $1.22 \mathrm{de}$ \\
$\mathrm{N}_{5}$ & $3.59 \mathrm{f}$ & $3.38 \mathrm{ef}$ & $2.54 \mathrm{ef}$ & $1.25 \mathrm{ef}$ \\
$\mathrm{N}_{6}$ & $3.78 \mathrm{f}$ & $3.56 \mathrm{f}$ & $2.67 \mathrm{f}$ & $1.33 \mathrm{f}$ \\
\hline
\end{tabular}

The correlation between winter wheat yield and precipitation over growing season was highly significant $(\mathrm{P}=0.01)$; and it was found significant $(\mathrm{P}=0.05)$ between winter wheat yield and precipitation over growing year (table 6). Table 6 showed that winter wheat yield was highly significant correlated with the available soil water in $0-3 \mathrm{~m}$ soil before sowing. This indicated that available soil water in $0-3 \mathrm{~m}$ soil before sowing and precipitation in growth period was the key impact factors to influence winter wheat yield on the Loess Plateau. Since the correlation index between winter wheat yield and available soil water in 0-7 $\mathrm{m}$ soil before sowing was significant $(\mathrm{P}=0.05)$, soil water in $0-7 \mathrm{~m}$ soil should be considered when to determine a sustainable fertilizer level for the winter wheat on the Loess Plateau.

Table 6. Winter wheat yield, precipitation and available soil water in different rainfall regions on the Loess Plateau of China

\begin{tabular}{|c|c|c|c|c|c|}
\hline \multirow{3}{*}{$\begin{array}{c}\text { Fainfall } \\
\text { region }\end{array}$} & \multirow{3}{*}{$\begin{array}{l}\text { Mean annual } \\
\text { yield }\left(\mathrm{t} / \mathrm{hm}^{2}\right)\end{array}$} & \multicolumn{4}{|c|}{ Correlation index between yield and } \\
\hline & & \multicolumn{2}{|c|}{ Precipitation over (mm) } & \multicolumn{2}{|c|}{ Available soil water before sowing in $(\mathrm{mm})$} \\
\hline & & Growing season & Growing year & 0-3 m soil & 0-7 m soil \\
\hline Luochuan & $2.77 \mathrm{a}$ & $0.66^{* *}$ & $0.42 *$ & $0.81^{* *}$ & $0.57 *$ \\
\hline Changwu & $2.70 \mathrm{~b}$ & $0.63 * *$ & $0.38 *$ & $0.78 * *$ & $0.60 *$ \\
\hline YanAn & $1.97 \mathrm{c}$ & $0.80^{* *}$ & $0.43 *$ & $0.80 * *$ & $0.70 *$ \\
\hline Shouyang & $1.00 \mathrm{~d}$ & $0.51 * *$ & $0.34 *$ & $0.79 * *$ & $0.68 *$ \\
\hline
\end{tabular}

Growing season of winter wheat was from September to June; growing year was from September to August.

\subsubsection{Soil Water}

2.2.2.1 Available Soil Water in $0-7 \mathrm{~m}$ Soil. With the increase amount of precipitation, more available soil water was founded in winter wheat field at luochuan and Changwu. Mean value of monthly available soil water in 0-7 m soil were 740, 
558, 512 and $412 \mathrm{~mm}$, with standard deviation of 102, 140, 137 and $99 \mathrm{~mm}$, at luochuan, Changwu, Yan'an and Shouyang respectively. Considering among different rainfall regions, precipitation was one of the key factors to impact the available soil water in winter wheat field.

The value of DS in different rainfall regions was different significantly. Table 7 showed more soil water decreased at Changwu and Yan'an, with the mean DS value of 113 and $114 \mathrm{~mm}$ respectively. Comparing with that in Shouyang, more precipitation and less DS value was founded at Changwu and Yan'an. Analysis of the winter wheat growth indicated the leaf area index (LAI) of winter wheat at Shouyang was significantly less than that at Changwu and Yan'an. It means that less transevaporation at Shouyang, comparing with that at Changwu and Yan'an. A highest value of LAI and precipitation was found at Luochuan. Though higher transevaporation (indicated by the high value of LAI) took place and may be decreased soil water, more precipitation added more water to the soil and decreased the DS value at Luochuan.

Comparing with $\mathrm{N}_{1}, \mathrm{~N}_{2}$ and $\mathrm{N}_{3}$ fertilizer level, a higher value of DS was founded in $\mathrm{N}_{4}, \mathrm{~N}_{5}$ and $\mathrm{N}_{6}$ fertilizer level. This indicated that more soil water decreased under the higher fertilizer level in winter wheat field on the Loess Plateau.

Table 7. Mean value of decreased available soil water from winter wheat was sowed to winter wheat was harvested

\begin{tabular}{cccccccc}
\hline & $\mathrm{N}_{0}$ & $\mathrm{~N}_{1}$ & $\mathrm{~N}_{2}$ & $\mathrm{~N}_{3}$ & $\mathrm{~N}_{4}$ & $\mathrm{~N}_{5}$ & $\mathrm{~N}_{6}$ \\
\hline Luochuan (mm) & 61 & 71 & 78 & 82 & 91 & 93 & 94 \\
Changwu (mm) & 85 & 99 & 109 & 116 & 125 & 126 & 130 \\
Yan'an (mm) & 86 & 100 & 111 & 111 & 127 & 128 & 131 \\
Shouyang (mm) & 76 & 86 & 93 & 99 & 104 & 106 & 111 \\
\hline
\end{tabular}

2.2.2.2 Development of Dry Soil Layer in 0-7m Soil. Fertilizer and rainfall were two key factors to effect the development of dry soil layer in winter wheat field on the Loess Plateau of China. Table 5 indicated that higher fertilizer level increased the winter wheat yield; at the same time increase the SD speed and the thickness of dry soil layer (table 8). Highest value of SD speed and highest SSL range were founded in N6 fertilizer level at four selected regions. With the increase amount of fertilizer applied to winter wheat, the value of SD and Max DSL increased (table 8). With the increasing amount of fertilizer level, more soil water was depleted and soil desiccation degree increased. More rainfall resulted in lower SD speed and SSL range in Luochuan and Changwu, comparing with that in Shouyang and Yan'an. 
Table 8. Statistical value of soil water distribution in $0-7 \mathrm{~m}$ soil in winter wheat field under different fertilizer levels in different rainfall regions on the Loess Plateau

\begin{tabular}{|c|c|c|c|c|c|c|c|c|c|}
\hline Rainfall region & $\begin{array}{l}\text { treat } \\
\text { ment }\end{array}$ & $\begin{array}{l}\text { SMDDT } \\
\text { Period }\end{array}$ & $\begin{array}{l}\text { SSMD } \\
\text { Year }\end{array}$ & $\begin{array}{l}\text { Max } \\
\text { DSL } \\
(\mathrm{m})\end{array}$ & $\begin{array}{l}\text { DSLD } \\
\text { Range } \\
(\mathrm{m})\end{array}$ & $\begin{array}{l}\text { SSL } \\
\text { Range } \\
(\mathrm{m})\end{array}$ & $\begin{array}{c}\text { SMC } \\
\text { Range } \\
(\mathrm{m})\end{array}$ & $\begin{array}{c}\text { SD } \\
\text { Speed } \\
(\mathrm{m} / \mathrm{a})\end{array}$ & $\begin{array}{l}\text { SWU } \\
\text { Depth } \\
\text { (m) }\end{array}$ \\
\hline \multirow[t]{7}{*}{ Luochuan } & $\mathrm{N}_{0}$ & $1960 \sim 1968$ & 1968 & 3 & $1 \sim 3$ & $2 \sim 3$ & $0 \sim 1$ & 0.38 & $2 \sim 3$ \\
\hline & $\mathrm{N}_{1}$ & $1960 \sim 1968$ & 1969 & 3 & $1 \sim 3$ & $2 \sim 3$ & $0 \sim 2$ & 0.33 & $2 \sim 3$ \\
\hline & $\mathrm{N}_{2}$ & $1960 \sim 1967$ & 1971 & 4 & $1 \sim 4$ & $2 \sim 4$ & $0 \sim 2$ & 0.36 & $>4$ \\
\hline & $\mathrm{N}_{3}$ & $1960 \sim 1967$ & 1970 & 4 & $1 \sim 4$ & $2 \sim 4$ & $0 \sim 2$ & 0.4 & $>4$ \\
\hline & $\mathrm{N}_{4}$ & $1960 \sim 1969$ & 1971 & 5 & $1 \sim 5$ & $2 \sim 5$ & $0 \sim 2$ & 0.42 & $>5$ \\
\hline & $\mathrm{N}_{5}$ & $1960 \sim 1968$ & 1971 & 5 & $1 \sim 5$ & $2 \sim 5$ & $0 \sim 2$ & 0.45 & $>5$ \\
\hline & $\mathrm{N}_{6}$ & $1960 \sim 1968$ & 1970 & 5 & $1 \sim 5$ & $2 \sim 5$ & $0 \sim 1$ & 0.5 & $>5$ \\
\hline \multirow[t]{7}{*}{ Changwu } & $\mathrm{N}_{0}$ & $1960 \sim 1968$ & 1969 & 3 & $1 \sim 3$ & $2 \sim 3$ & $0 \sim 2$ & 0.33 & $2 \sim 3$ \\
\hline & $\mathrm{N}_{1}$ & $1960 \sim 1967$ & 1968 & 3 & $1 \sim 3$ & $2 \sim 3$ & $0 \sim 2$ & 0.38 & $2 \sim 3$ \\
\hline & $\mathrm{N}_{2}$ & $1960 \sim 1967$ & 1971 & 4 & $1 \sim 4$ & $2 \sim 4$ & $0 \sim 2$ & 0.36 & $>4$ \\
\hline & $\mathrm{N}_{3}$ & $1960 \sim 1968$ & 1970 & 4 & $1 \sim 4$ & $2 \sim 4$ & $0 \sim 2$ & 0.4 & $>4$ \\
\hline & $\mathrm{N}_{4}$ & $1960 \sim 1966$ & 1972 & 5 & $1 \sim 5$ & $2 \sim 5$ & $0 \sim 2$ & 0.45 & $>5$ \\
\hline & $\mathrm{N}_{5}$ & $1960 \sim 1966$ & 1971 & 5 & $1 \sim 5$ & $2 \sim 5$ & $0 \sim 1$ & 0.45 & $>5$ \\
\hline & $\mathrm{N}_{6}$ & $1960 \sim 1966$ & 1970 & 5 & $1 \sim 5$ & $2 \sim 5$ & $0 \sim 1$ & 0.5 & $>5$ \\
\hline \multirow[t]{7}{*}{ Yan'an } & $\mathrm{N}_{0}$ & $1960 \sim 1966$ & 1967 & 3 & $1 \sim 3$ & $2 \sim 3$ & $0 \sim 2$ & 0.43 & $2 \sim 3$ \\
\hline & $\mathrm{N}_{1}$ & $1960 \sim 1966$ & 1967 & 3 & $1 \sim 3$ & $2 \sim 3$ & $0 \sim 2$ & 0.43 & $2 \sim 3$ \\
\hline & $\mathrm{N}_{2}$ & $1960 \sim 1966$ & 1969 & 4 & $1 \sim 4$ & $2 \sim 4$ & $0 \sim 2$ & 0.44 & $>4$ \\
\hline & $\mathrm{N}_{3}$ & $1960 \sim 1965$ & 1968 & 4 & $1 \sim 4$ & $2 \sim 4$ & $0 \sim 2$ & 0.5 & $>5$ \\
\hline & $\mathrm{N}_{4}$ & $1960 \sim 1965$ & 1969 & 5 & $1 \sim 5$ & $2 \sim 5$ & $0 \sim 2$ & 0.56 & $>5$ \\
\hline & $\mathrm{N}_{5}$ & $1960 \sim 1965$ & 1968 & 5 & $1 \sim 5$ & $2 \sim 5$ & $0 \sim 1$ & 0.63 & $>5$ \\
\hline & $\mathrm{N}_{6}$ & $1960 \sim 1965$ & 1968 & 5 & $1 \sim 5$ & $2 \sim 5$ & $0 \sim 2$ & 0.63 & $>5$ \\
\hline \multirow[t]{7}{*}{ Shouyang } & $\mathrm{N}_{0}$ & $1960 \sim 1966$ & 1966 & 3 & $1 \sim 3$ & $2 \sim 3$ & $0 \sim 1$ & 0.5 & $2 \sim 3$ \\
\hline & $\mathrm{N}_{1}$ & $1960 \sim 1965$ & 1966 & 3 & $1 \sim 3$ & $2 \sim 3$ & $0 \sim 2$ & 0.5 & $2 \sim 3$ \\
\hline & $\mathrm{N}_{2}$ & $1960 \sim 1965$ & 1968 & 4 & $1 \sim 4$ & $2 \sim 4$ & $0 \sim 2$ & 0.5 & $>4$ \\
\hline & $\mathrm{N}_{3}$ & $1960 \sim 1965$ & 1967 & 4 & $1 \sim 4$ & $2 \sim 4$ & $0 \sim 2$ & 0.57 & $>5$ \\
\hline & $\mathrm{N}_{4}$ & $1960 \sim 1965$ & 1968 & 5 & $1 \sim 5$ & $2 \sim 5$ & $0 \sim 2$ & 0.63 & $>5$ \\
\hline & $\mathrm{N}_{5}$ & $1960 \sim 1965$ & 1967 & 5 & $1 \sim 5$ & $2 \sim 5$ & $0 \sim 2$ & 0.71 & $>5$ \\
\hline & $\mathrm{N}_{6}$ & $1960 \sim 1965$ & 1967 & 5 & $1 \sim 5$ & $2 \sim 5$ & $0 \sim 1$ & 0.71 & $>5$ \\
\hline
\end{tabular}




\subsubsection{WUEG and IRFG}

Table 9 showed the value of WUEG increased, with increase application of fertilizer to winter wheat field. Mean value of WUEG among different regions for $\mathrm{N}_{0}, \mathrm{~N}_{1}, \mathrm{~N}_{3}$, $\mathrm{N}_{2}, \mathrm{~N}_{4}, \mathrm{~N}_{5}$ and $\mathrm{N}_{6}$ fertilizer level were 2.76, 3.80, 4.83, 5.57, 6.32, 6.59 and 6.92 $\mathrm{t} /\left(\mathrm{hm}^{2} \cdot \mathrm{mm}\right)$ respectively. Among different rainfall regions, WUEG increased with the increasing of annual rainfall at Luochuan, Changwu, Yan' an and Shouyang (table 9).

From $\mathrm{N}_{1}$ to $\mathrm{N}_{4}$ fertilizer level, the value of IRFG increased with the increase of fertilizer applied to the winter wheat field (table 9). From $\mathrm{N}_{4}$ to $\mathrm{N}_{5}$ fertilizer level, a contrary changing trend was founded for the value of IRFG. The value of IRFG became lower, when the fertilizer was more than $180 \mathrm{~kg} / \mathrm{hm}^{2}$. Among different rainfall regions, the value of IRFG was the highest at Luochuan, it was the second at Changwu, and the lowest value was at Shouyang (table 9). Annual rainfall was one of the key factors to influence fertilizer using efficiency on the Loess Plateau of China.

Table 9. Comparison of WUEG among different fertilizer levels and different rainfall regions on the Loess Plateau of China

\begin{tabular}{ccccccccc}
\hline Rainfall regions & items & $\mathrm{N}_{0}$ & $\mathrm{~N}_{1}$ & $\mathrm{~N}_{2}$ & $\mathrm{~N}_{3}$ & $\mathrm{~N}_{4}$ & $\mathrm{~N}_{5}$ & $\mathrm{~N}_{6}$ \\
\hline \multirow{2}{*}{ Luochuan } & WUEG $\left(\mathrm{t} /\left(\mathrm{hm}^{2} \cdot \mathrm{mm}\right)\right)$ & 3.14 & 4.73 & 6.37 & 7.22 & 8.38 & 8.76 & 9.19 \\
& IRFG $\left(\mathrm{t} /\left(\mathrm{hm}^{2} \cdot \mathrm{kg}\right)\right)$ & -- & 0.70 & 1.11 & 1.20 & 1.24 & 1.14 & 1.08 \\
\multirow{5}{*}{ Changwu } & WUEG $\left(\mathrm{t} /\left(\mathrm{hm}^{2} \cdot \mathrm{mm}\right)\right)$ & 3.53 & 4.61 & 5.63 & 6.50 & 7.24 & 7.55 & 7.93 \\
& IRFG $\left(\mathrm{t} /\left(\mathrm{hm}^{2} \cdot \mathrm{kg}\right)\right)$ & -- & 0.56 & 0.84 & 0.95 & 1.00 & 0.92 & 0.88 \\
\multirow{3}{*}{ Yan'an } & WUEG $\left(\mathrm{t} /\left(\mathrm{hm}^{2} \cdot \mathrm{mm}\right)\right)$ & 2.67 & 3.66 & 4.58 & 5.33 & 6.07 & 6.35 & 6.66 \\
& IRFG $\left(\mathrm{t} /\left(\mathrm{hm}^{2} \cdot \mathrm{kg}\right)\right)$ & -- & 0.43 & 0.67 & 0.75 & 0.82 & 0.75 & 0.71 \\
\multirow{2}{*}{ Shouyang } & WUEG $\left(\mathrm{t} /\left(\mathrm{hm}^{2} \cdot \mathrm{mm}\right)\right)$ & 1.71 & 2.20 & 2.73 & 3.23 & 3.58 & 3.70 & 3.91 \\
& IRFG $\left(\mathrm{t} /\left(\mathrm{hm}^{2} \cdot \mathrm{kg}\right)\right)$ & -- & 0.18 & 0.30 & 0.36 & 0.38 & 0.34 & 0.33 \\
\hline
\end{tabular}

\section{Discussions}

\subsection{Fertilizer, Dry Soil Layer and Rainfall}

Nitrogen fertilizer stimulated the winter wheat root to develop into the deeper soil, and using more deep soil water [23]. However, once dry soil layer built in deep soil, it was difficult to recover on the Loess Plateau [24]. Therefore, the use of high fertilization rates has been found to increase the thickness of dry soil layer [25] and resulted the fluctuation of winter wheat yield in different rainfall years on the Loess Plateau [6]. This paper showed that more soil water in deep soil depleted and the SD speed (soil desiccation speed) increased, with the increasing application of fertilizer for winter wheat. The amount of annual rainfall impacted the develop speed of dry soil layers in different regions. Comparing with Luochuan and Changwu, higher value of SD speed was founded at Yan'an and Shouyang. 


\subsection{Fertilizer, WUEG and IRFG}

The increasing use of deep soil water during critical crop development stages increased the value of WUEG (water use efficiency for grain yield) for high fertilizer winter wheat [5]. Various study found that water and fertilizer related and impacted each other [26-27]. This study indicated higher value of IRFG and WUEG in higher fertilizer level field, when no dry soil layer build in deep soil; while lower IRFG value in higher fertilizer level field, when dry soil layers had been built in deep soil.

\subsection{Sustainable Fertilizer Level for Winter Wheat Field}

At Luochuan, the difference of winter wheat yield for $\mathrm{N}_{5}$ and $\mathrm{N}_{6}$ fertilizer level was not significant; there was not significant difference between winter wheat yield for $\mathrm{N}_{5}$ and $\mathrm{N}_{6}$ at Changwu and Yan'an, and also for $\mathrm{N}_{4}$ and $\mathrm{N}_{5}$ fertilizer level was not significant; At Shouyang, there was no significant difference between winter wheat yield for $\mathrm{N}_{5}$ and $\mathrm{N}_{6}, \mathrm{~N}_{4}$ and $\mathrm{N}_{5}, \mathrm{~N}_{3}$ and $\mathrm{N}_{4}$. These statistical results indicated that fertilizer level should not be higher than $\mathrm{N}_{5}, \mathrm{~N}_{4}, \mathrm{~N}_{4}$ and $\mathrm{N}_{3}$, at Luochuan, Changwu, Yan'an and Shouyang respectively.

When dry soil layers develop to more than $5 \mathrm{~m}$ depth, it will become more difficult to recover [28] on the Loess Plateau of China. Table 8 showed that the depth of dry soil layer was deeper than $5 \mathrm{~m}$ for $\mathrm{N}_{4}, \mathrm{~N}_{5}$ and $\mathrm{N}_{6}$ at Luochuan and Changwu; for $\mathrm{N}_{3}$, $\mathrm{N}_{4}, \mathrm{~N}_{5}$ and $\mathrm{N}_{6}$ at Yan'an and Shouyang. Therefore, considering on the recovery of dry soil layers, fertilizer level for winter wheat should not be higher than $\mathrm{N}_{4}$ at Luochuan and Shouyan; and it should not be higher than $\mathrm{N}_{3}$ at Yan'an and Shouyang. Table 9 indicated the value of IRFG became lower when the fertilizer level was higher than $\mathrm{N}_{4}$ for winter wheat field, either at Luochuan and Changwu or at Yan'an and Shouyang. This result indicated the fertilizer using efficiency decreased when fertilizer level was higher than $\mathrm{N}_{4}$ for winter wheat field.

Considering on the sustainable production of winter wheat and the sustainable using of soil water, the fertilizer level for the different rainfall regions on the Loess Plateau should as followed. 1) In the semi-humid region (Luochuan), fertilizer level should be from $\mathrm{N}_{4}$ to $\mathrm{N}_{5} ; 2$ ) in the semi-humid and drought-prone region (Changwu) and in the semi-arid region (Yan'an), it should be from $\mathrm{N}_{3}$ to $\mathrm{N}_{4} ; 3$ ) in the semi-arid and drought-prone region (Shouyang), it should be lower than $\mathrm{N}_{3}$.

\section{Conclusions}

The EPIC model simulated the variance of winter wheat yield among different fertilizer levels well, with the mean $\mathrm{R}$ value of 0.91 ; and it estimated mean annual available soil water well, with the mean $\mathrm{R}$ vale of 0.89 , on the Loess Plateau of China.

Soil desiccation speed increased with the increasing of fertilizer applied to winter wheat field; and it decreased with the increasing of annual rainfall in different rainfall regions on the Loess Plateau of China. 
With the increase application of fertilizer, the value of IRFG and WUEG became higher, when soil water in deep soil was not be used excessively; the value of IRFG became lower, when soil water in deep soil was used excessively.

Sustainable fertilizer levels for winter wheat on the Loess Plateau were different for different rainfall regions. 1) In the semi-humid region (Luochuan), it should be from $\mathrm{N}_{4}$ to $\mathrm{N}_{5} ; 2$ ) in the semi-humid and drought-prone region (Changwu) and in the semi-arid region (Yan'an), it should be from $\mathrm{N}_{3}$ to $\mathrm{N}_{4} ; 3$ ) in the semi-arid and drought-prone region (Shouyang), it should be lower than $\mathrm{N}_{3}$.

Acknowledgment. This study was sponsored by the Knowledge Innovation Program of Chinese Academy of Sciences (KZCX2-YW-JC408), sub research item (2009CB118604) of the National Basic Research Program of China (973 Program) and the Key Projects in the National Science \& Technology Pillar Program (2011BAD31B01). We are grateful to Williams J.R. with whom we had many discussions about the EPIC model. We want to give our thanks to the students who had done a great work for the field experiment at Chanwu Agricultural Station. We also want to give our thanks to two anonymous reviewers for their helpful comments on the earlier version of this paper.

\section{References}

[1] Zhu, X.: Soil and Agriculture in the Loess Plateau. Agricultural Science Press, Beijing (1989) (in Chinese)

[2] Brown, P.L.: Water use and soil-water depletion by dryland winter wheat as affected by nitrogen fertilization. Agron. J. 63, 43-46 (1971)

[3] Read, D.W.L., Warder, F.G., Cameron, D.R.: Factors affecting fertilizer nitrogen response of wheat insouthwestern Saskatchewan. Can. J. Soil Sci. 62, 577-586 (1982)

[4] Ritchie, J.T., Johnson, B.S.: Soil and plant factors affecting evaporation. In: Stewart, B.A., Nielsen, D.R. (eds.) Irrigation of Agricultural Crops, Agronomic Monograph, ASA, CSSA, SSSA, Madison, WI, USA, vol. 30, pp. 363-390 (1990)

[5] Huang, M.B., Dang, T.H., Jacques, G., Monique, G.: Effect of increased fertilizer applications to wheat crop on soil-water depletion in the Loess Plateau, China. Agricultural Water Management 58, 267-278 (2003)

[6] Li, Y.S.: Fluctuation of yield on high-yield field and desiccation of the soil on dryland. Chin. J. Acta Pedol. Sin. 38(3), 353-355 (2001)

[7] Zhang, L., Dawes, W.: WAVES-An Integrated Energy and Water Balance Model, CSIRO Land and Water Technical Report no. 31/98, Australia (1998)

[8] Van Genuchten, M.T.: A Numerical Model for Water and Solute Movement in and Below the Root Zone. Research Report No. 121. US Salinity Laboratory, USDA, ARS, Riverside, CA (1987)

[9] Jones, J.W., Batchelor, W.D., Hoogenboom, G., Porter, C.H., Boote, K.J., Hunt, L.A., Wilkens, P.W., Singh, U., Gijsman, A.J., Ritchie, J.T.: The DSSAT cropping system model. Europ. J. Agron. 18, 235-265 (2003)

[10] Williams, J.R., Jones, C., Dyke, P.T.: A modeling approach to determining the relationship between erosion and soil productivity. Trans. ASAE 27, 129-144 (1984)

[11] Wang, X.C., Li, J.: Evaluation of crop yield and soil water estimates using the EPIC model for the Loess Plateau of China. Math. Comput. Model 51, 1390-1397 (2010) 
[12] Bennie, A.T.P., Taylor, H.M., Georgen, P.G.: An assessment of the core-break method for estimating root density of different crops in the field. Soil Tillage Res. 9(24), 343347 (1987)

[13] Blake, G.R., Hartge, K.H.: Bulk density. In: Klute, A. (ed.) Methods of Soil Analysis. Part I. Physical and Mineralogical Methods, pp. 363-382. American Society of Agronomy, Madison (1986)

[14] Williams, J.R., Jones, C.A., Kiniry, J.R., Spanel, D.A.: The EPIC crop growth model. Trans. ASAE 32, 497-511 (1989)

[15] Williams, J.R.: The EPIC model. In: Singh, V.P. (ed.) Computer Models of Watershed Hydrology. Water Resources Publications, Highlands Ranch (1995)

[16] Robert, A.B., Norman, J.R.: Sensitivity of crop yield and water use to change in a range of climatic factors and $\mathrm{CO}$, concentrations: a simulation study applying EPIC to the central USA. Agr. Forest. Meteorol. 83, 171-203 (1997)

[17] Niu, X.Z., Easterling, W., Hays, C.J., Jacobs, A., Mearns, L.: Reliability and input-data induced uncertainty of the EPIC model to estimate climate change impact on sorghum yields in the U.S. Great Plains. Agric. Ecosys. Environ. 129, 268-276 (2009)

[18] Izaurralde, R.C., Williams, J.R., McGill, W.B., Rosenberg, N.J., Quiroga Jakas, M.C.: Simulating soil $\mathrm{C}$ dynamics with EPIC: Model description and testing against longterm data. Ecol. Model. 192, 362-384 (2006)

[19] Williams, J.R., Jones, C.A., Dyke, P.T.: The EPIC Model. In: Williams, J.R. (Eds.), EPIC-Erosion Productivity Impact Calculator. 1. Model Documentation. pp. 3-86, U.S. Department of Agriculture Technical Bulletin No. 1768 (1990)

[20] Ko, J., Piccinni, G., Stelich, E.: Using EPIC model to manage irrigated cotton and maize. Agric. Water Manag. 96, 1323-1331 (2009)

[21] Hussain, G., Al-Jaloud, A.A.: Effect of irrigation and nitrogen on water use efficiency of wheat in Saudi Arabia. Agric. Water Manage. 27, 143-153 (1995)

[22] SPSS Inc., SPSS for Windows Base System User's Guide Release 6.0. Marija J. Norusis/SPSS Inc. (1977)

[23] Nielsen, D.C., Halvorson, A.D.: Nitrogen fertility influence on water stress and yield of winter wheat. Agron. J. 83, 1065-1070 (1991)

[24] Wang, X.L., Chen, M.C., Li, F.M., Li, Y.J.: Water restoration of dry soil layers in the Loess Plateau and crop yield response. Res. Soil Water Conserv. 14(3), 1-4 (2007)

[25] Wang, X.C., Li, J., Jiang, B., Hu, W.: Simulation of yield and soil desiccation effects of continuous spring maize in different precipitation areas of the Loess Plateau. Acta Ecol. Sin. 29(4), 2053-2066 (2009)

[26] Mitchell, C.C., Westerman, R.L., Brown, J.R., Peck, T.R.: Overview of long-term agronomic research. Agron. J. 83, 24-29 (1991)

[27] Sandor, J.A., Eash, N.S.: Significance of ancient agriculture soils for long-term agronomic studies and sustainable agriculture research. Agron. J. 83, 29-37 (1991)

[28] Wang, X.C., Muhammad, T.N., Hao, M.D., Li, J.: Sustainable recovery of soil desiccation in semi-humid region on the Loess Plateau. Agric. Water Manage. 98, 1262-1270 (2011) 